This item was submitted to Loughborough's Research Repository by the author.

Items in Figshare are protected by copyright, with all rights reserved, unless otherwise indicated.

\title{
Hybrid hegemonic masculinity of the EU before and after the Arab Spring: a gender analysis of Euro-Mediterranean security relations
}

PLEASE CITE THE PUBLISHED VERSION

http://dx.doi.org/10.1080/13629395.2014.950472

\section{PUBLISHER}

(C) Taylor \& Francis

\section{VERSION}

AM (Accepted Manuscript)

\section{PUBLISHER STATEMENT}

This work is made available according to the conditions of the Creative Commons Attribution-NonCommercialNoDerivatives 4.0 International (CC BY-NC-ND 4.0) licence. Full details of this licence are available at: https://creativecommons.org/licenses/by-nc-nd/4.0/

\section{LICENCE}

CC BY-NC-ND 4.0

\section{REPOSITORY RECORD}

Bilgic, Ali. 2015. "Hybrid Hegemonic Masculinity of the EU Before and After the Arab Spring: A Gender Analysis of Euro-mediterranean Security Relations". Loughborough University. https://hdl.handle.net/2134/26208. 
Accepted Version

Hybrid Hegemonic Masculinity of the EU before and after the Arab Spring:

\section{A Gender Analysis of Euro-Mediterranean Security Relations}

\section{Ali Bilgic}

\section{Abstract:}

In the academic literature on EU-Southern Mediterranean relations, a focal point of neglect has been the gendered dimension of Euro-Mediterranean relations. This article will argue that the EuroMediterranean space has been formed within the gendered global West/non-West relations with the purpose of promoting the West's security interests. Euro-Mediterranean security relations, thus, embody a gendered power hierarchy between the hybrid hegemonic masculinity of the EU (bourgeois-rational and citizen-warrior) and the subordinate (both feminized and hypermasculinized) Southern neighbourhood. In addition, it will be shown that after the Arab Spring, the EU has been determined to maintain the status quo by re-constructing these gendered power relations. This gender analysis contributes to the literature on Euro-Mediterranean relations through its specific focus on the (re)construction processes of gendered identities within the West/non-West context in tandem with EU's competing notions of security.

Keywords: European Union, Mediterranean, Security, Gender, Arab Spring 
In the literature on the relations between the European Union (EU) and Southern Mediterranean countries (heretofore, Euro-Mediterranean relations), the issue of gender has appeared sporadically as one of the several dimensions of the EU's policy towards its Southern neighbourhood (Schmid, 2004; Lister and Carbone, 2006; Kausch and Youngs, 2009; Debusscher, 2012). Several studies introduce the issue from the perspective of the Southern Mediterranean by evaluating the ostensible contributions of feminist civil society in pursuing a more substantial democracy promotion agenda in North Africa (for example, Jünemann, 2002). Yet, a gender perspective indicates a major and deeper gap. In the literature, apart from a few studies which argue in favour of gendering security as a way of better realization of 'human security' or 'soft security' (Jünemann, 2003; Harders, 2003), gender analysis of the security relations, processes and structures in the Euro-Mediterranean area remains weak. Simply put, relevant studies have almost always neglected that Euro-Mediterranean security relations are gendered. This entails that power operates through the construction of hierarchical hybrid gendered identities with the purpose of promoting certain security interests as an embodiment of global West/non-West relations.

This article will problematize Euro-Mediterranean security relations by situating it within the global West/non-West relations and its gendered construction. It will be argued that a hybrid EuroMediterranean space has been constructed through feminizing and hypermasculinizing the Southern Mediterranean in order to justify the West's intervention into the region and to promote EU security interests. This leads to hyperfeminization of individuals and societies and to subordination of their security concerns to those of the EU. Although the Arab Spring emerged as a process in which individuals and societies resisted the mechanisms that hindered their security, the EU has been determined to maintain the status quo by preserving gendered power relations. The first theoretical section of this article will discuss the operationalizations of theory of masculinities particularly within context of the West/non-West relations. The purpose is to examine how different masculinities are constructed in relation to different notions of security. This helps to explain the hybridity of the EuroMediterranean space. Based on this theoretical foundation, the second section will perform a feminist reading of the Euro-Mediterranean security relations since its institutionalisation in 1995 Barcelona Process. Specifically, it will analyse how power relations have been (re)constructed through gendered identities with regard to EU notions of security. In the final section, the analysis will direct its scope towards post-Arab Spring EU reactions and will examine the extent to which the EU is reiterating the power hierarchy.

The gender analysis will pursue three objectives. First, it aims to contribute to the growing literature on non-liberal security practices in liberal orders within the context of West/non-West relations. 
Laffey and Nadarajah (2012: 404) argue that this "has encompassed both liberal and non-liberal subjects and spaces, in Europe and its imperial and colonial extensions, generating practices and apparatuses of rule that are also hybrid in nature.' The present analysis explains this hybridity by revealing the complexities of gendered identities constructed through/within Euro-Mediterranean security relations. As Agathangelou (2013: 32) argues, global structures and their reiteration largely depend on gendering individuals, social groups, geographies and communities. Following this, it is argued that feminization and hypermasculinization are essential tools for the construction of the Euro-Mediterranean hybrid space. Second, this analysis aims to bring the gender dimension into the growing critical literature about Euro-Mediterranean security relations with specific focus on the externalization process and its consequences. Agathangelou (2004) discusses the issue of sex trafficking and insecurities associated with it in the Euro-Mediterranean area. This analysis will broaden the gender perspective by including new issues such as democracy promotion and counterterrorism in the new framework of hybridity of masculinities, and by specifically focusing on how the EU constructs a Euro-Mediterranean space by recourse to gender hierarchies. Finally, this discussion aims to evaluate whether there has been a change after the Arab Spring within the gendered spatial construction of the Euro-Mediterranean.

\section{Masculinities and Security: (Re)Production of Power Relations in the West/non-West Context}

Some feminists argue that in global politics, power does not solely operate through a single dichotomy between masculinity and femininity. Understanding and problematizing global power relations require a conception of gender that transcends the dichotomy between single/universal dominant masculinity and subordinated femininity (Zalewski, 1998 and 2010: 37-40). Especially with the emergence of Third World feminism which successfully examines Western and non-Western masculinities in colonial and post-colonial contexts (Mohanty, 2010), many feminists start to focus on 'the politics of masculinity as a contested field of power moves and resistances' (Hooper, 1998: 29). In this contested field, different masculinities interact; some of them hold dominating positions, while others are marginalized. How power is institutionalized in and through gendered practices, and for whom the gendered relations of domination work, can be grasped comprehensively by extending the analytical scope to discuss masculinity as a contingent, fluid, multidimensional and pluralistic phenomenon (Beasley, 2008: 87). Therefore, understanding the relations between different masculinities has become central for feminism, which aims to reveal the gendered dimension of power relations and thus transform them (Tickner and Sjoberg, 2011: 227). The gendered hierarchy of multiple masculinities has enabled feminist IR scholars to approach masculinities along three lines: 
historicization of masculinities, hierarchy of masculinities within the context of West/non-West relations, and contending security notions in relation to different masculinities.

Firstly, IR feminists examine how masculinities have been historically transformed, and therefore, evolved to survive by being constitutive to political, social and economic conditions. For the purposes of this analysis, two models of masculinity should be explained. 'The citizen-warrior masculinity' model carries strong patriarchal elements (such as domination and control) combined with aggressiveness and materialistic power use in order to secure what is considered as the domestic. In 'the bourgeois-rationalist model', on the other hand, 'superior intellect and personal integrity is valued over physical strength or bravery' (Hooper, 2001: 98, see also Hooper, 1998). By having an enlightened self-interest, patriarchal domination of others is overlaid by guidance and persuasion. In this sense, it is more egalitarian and democratic, and also less aggressive. Emanating from the Enlightenment's moral and political philosophy, the emergence and gradual construction of hegemony of bourgeois-rational model points to the contingency of masculinities (Hooper, 2001: 97). These masculinities can occupy 'the hegemonic position' over other 'subordinated' masculinities (Connell, 2005: 71).

The contingency and historicity of masculinities leads some feminists in IR to question the ontology of hegemonic masculinity: if masculinities are constantly in production (constitutive of subjectivities), is it possible to ascertain any type of masculinity as hegemonic? (Eichler, 2011) It is indeed the case that hegemonic and subordinated masculinities often take odd forms in global politics depending on social, political and economic conditions, while defying a monolithic and timeless analysis of masculinities (see, Elder, 2005; Munn, 2008). However, as postcolonial feminists forcefully show, contingency of masculinities does not necessarily mean that we can dismiss global political and economic structures that produce gendered individuals, societies and states in the context of West/non-West relations. This structural dimension sometimes manifests itself as 'liberal international order' which feminizes the non-West, and therefore, reproduces hegemony of the West over non-Western states, societies and individuals (Ling, 2002). It is sometimes referred to as 'neocolonialism' which reproduces hierarchical power relations deriving from race, gender, sexuality and class globally (Agathangelou and Ling, 2009: 2).

Secondly, as gender 'is unavoidably involved with other social structures' (Connell, 2005: 75), the analytical focus on the relational dimension of masculinities has paved the way for studying the global constitution of gendered identities and other identities including race, class and sex. In feminist IR literature, these complex relations manifest as West/non-West, North/South, citizens/non-citizen, heterosexual/homosexual, White/non-White, and capitalist/non-capitalist (Ouzgane and Coleman, 
1998; Han and Ling, 1998; Ling, 2000; Hooper, 2001; Kronsell, 2005). Gender is instrumental to constructing these dichotomies where 'the other' is represented as subordinated to 'the self', which feminizes or hypermasculinizes 'the other'. For the purposes of this analysis, hierarchical relations between masculinities in global politics are specifically taken in the context of West/non-West relations. The power hierarchy between West and non-West is constructed and reconstructed through hypermasculinizing and feminizing the non-West, which is reproduced as 'subordinate' to the West. In the case of hypermasculinization, the non-West is represented as authoritarian, barbaric, violent, reactionary, irrational (or sometimes possessing 'cold rationality') (Agathangelou and Ling, 2004). Feminization of the non-West, on the other hand, constructs it as passive, emotional, weak (Han and Ling, 1998: 60-62). The non-West, therefore, becomes 'the other' of the West (Spurr, 1993; Doty, 1996). This self/other identity constructions through the gendered representation of the nonWest is essential for the spatial construction of the non-West as an underdeveloped, uncivilized, nonmodern geography that requires the West's intervention and penetration to re-order (Slater, 2004: 223). Hence, the non-West as a geographical space is produced and instrumentalized for the political, economic and social reproduction of the West within the West/non-West gendered power hierarchy.

Situating Euro-Mediterranean relations within the West/non-West gendered power hierarchies, since the mid-1990s, the EU's policies at multiple levels have spatially constructed a Southern neighbourhood that constantly needs the EU's political guidance and financial tools as hypermasculinized and feminized region. This analysis will specifically look at how the Southern neighbourhood of the EU as the non-West is instrumentalized through gendering for the security interests of the EU. This leads us to the third point.

The third dimension of the analysis of multiple masculinities unpacks the interaction of notions of security with the construction of hierarchical gendered identities in West/non-West relations. Political identities that represent masculinities are constructed, consolidated or transformed in relation to the security notions of political actors. A masculine identity based on the citizen-warrior model is constitutive to the (neo)realist notion of security feeding into statism, inside/outside dichotomy, and militarism. Aggressiveness in order to secure 'the domestic' and the values inside the borders is accepted as a norm (Hooper, 2001: 103-105). The bourgeois-rational model of masculinity, on the other hand, has a more democratic and liberal approach to security. This type of masculinity manifests in liberal transnationalism, as opposed to the Machiavellian world of (neo)realism (Hooper, 2001: 103-105). Hence its security notion revolves around a liberal-pluralist approach. Democratization and promotion of human rights (and the establishment of a free-market economy as a means to achieve this) are crucial components of pursuit of security not also domestically but also internationally. Therefore, political actors adopting this masculinity aim to secure themselves by 
promoting liberal values outside their borders and by being a model for others (see Tickner, 1992). How does the security notions/masculinities nexus work in the context of West/non-West relations?

Notions of security (meaning, ideas and practices about what to be secured and how to be secured) are constitutive to the construction processes of hegemonic Western and subordinate non-Western masculine identities. The spatial construction of the non-West through feminizing and hypermasculinizing is practiced with the trajectory of promoting the West's security interests. This means that representations of the non-West are constitutive to the notions of security in the West. Hypermasculine representations of the non-West as an excessively violent, barbaric, irrational space produce security notions that prioritize domination and militarization as responses to the violent other. Feminization of the non-West is also a threat to the West's security because of its incapacity to performing or failure to keep up with the modern, democratic, 'Western' state. For example, this 'failure' rendered them a fertile ground for communism to take root during the Cold War (Slater, 2004: 124). In contemporary global politics, non-Western states are sometimes represented as a source of fundamentalist terrorism (Biswas, 2002), and sometimes as a source of 'illegal migrants' with their peripheral economies (Agathangelou, 2004: 106-110). In both cases, the West is the referent of security. An interesting dimension this analysis reveals is that while the gendered nonWest is represented as a threat to the West, the latter sometimes intentionally feminizes and hypermasculinizes the former to pursue its security interests. It will be shown how the non-West in the form of Southern neighbourhood of the EU is spatially constructed and instrumentalized as an agent of Western security through gendered representations.

The exploration of the mutually constitutive relationship between the construction of gendered identities and notions of security unpacks Euro-Mediterranean security relations. Since the institutionalisation of Euro-Mediterranean relations, the EU's masculine identity (European, liberal, proactive, father, but sometimes aggressive) vis-à-vis that of North Africa (non-European, authoritarian, reactive, son) has been built upon reflecting two different security notions: (1) the security notion which relies on the promotion of democratic pluralism and human rights in its immediate neighbourhood and (2) the security notion that has been operationalized as 'externalization'. These notions are constitutive to the construction of a hybrid hegemonic masculinity for the EU. On the one hand, this masculinity reflects the bourgeois-rational model, which has been increasingly fed by the (neo)liberal vision to spread particular political values and a market economy. On the other hand, in relation to certain political issues, the citizen-warrior model dominates hegemonic masculinity, which generates security practices underlined by militarization and domination. This model involves hypermasculine characteristics, which means exaggerated aggression, oppression, higher tendency to inflict violence, sometimes in tandem with cold 
instrumental rationality. What is fundamental for this analysis is that regarding certain political issues, the EU has reinforced hypermasculine subordinate masculinity and externalized hypermasculinised security practices in the Southern neighbourhood by constructing various 'threatening others'.

The gendered representations of the non-West in compatibility with the West's security notions are articulated through the process of constructing the self/other dichotomy, which has two dimensions. The first one is about otherizing the non-West as a threat to the security of the Western self, as discussed previously. In the context of Euro-Mediterranean security relations, the Southern Mediterranean is hypermasculized and feminized as the other of the EU and as a threat to the security of the self. In certain areas such as democratization and human rights promotion, the EU's bourgeois-rational masculinity aims to guide 'the other' through adopting political and financial instruments developed by the EU so they can follow the EU member states' political and economic structures. In other words, it is expected that the Southern neighbourhood emulate the EU, although this does not lead to an abolition of the self/other dichotomy. ${ }^{1}$ The second dimension is the hypermasculinization of Southern Mediterranean. Hypermasculinity is conceptualized in postcolonial feminist literature primarily by Nandy (1983) in the case of India, where both the colonizer and the colonized value excessive aggressiveness against each other. Ling uses the concept to explain the way Asian economies react to recast 'economic development into a retrieval of cultural-national manhood' against Western capitalist hypermasculinity (Ling, 2002: 118, see also, Ling, 2000). However, in the case of Euro-Mediterranean relations and issues such as migration and counterterrorism cooperation, the hypermasculinity of the non-Western other is not simply a reaction and a threat to the West for distorting the feminized non-West. It becomes a quality that the EU can utilize.

The second dimension of the self/other dichotomy is the construction of 'threatening others' who are targeted by hypermasculine practices in Southern Mediterranean. Postcolonial literature reveals that the gendered self/other construction is strongly detectable in non-Western contexts, especially when the non-Western state begins to emulate the Western model of modern, liberal, and developed state (Agathangelou, 2004: 106). It is shown that one of the most important dimensions of 'postcolonial insecurities' is the generation of insecurity towards the constructed 'others' (Das, 2003). While in some cases, the 'other' is ethno-religious minorities and dissidents; it can sometimes be another state (Muppidi, 1999) or the whole 'West' itself (Niva, 1999). 'The other' in different contexts is feminized as weak and emotional, but generally hypermasculinized as a violent threat to the self. In this way, violent responses are justified while the agent of security, which is either a postcolonial state

\footnotetext{
${ }^{1}$ This is different from 'mimicry' which is a survival strategy of the colonized by emulating the colonizer, see Bhabha, 1994 and Ling, 2002: 116-117. In this analysis, emulation is encouraged by the EU to create a nonthreatening non-Western space.
} 
or a leader of non-state entity, is reproduced as the sole representative of the non-western self (Agathangelou and Ling, 2009: 17-21).

Agathangelou (2004) shows that Euro-Mediterranean relations are gendered with specific reference to the economy of sex and domestic labour which produces racialized, sexualized and commodified women and men as sex workers, prostitutes, housemaids, and traffickers. The desire of 'white but not quite' locals on Cyprus, Turkey and Greece to African and 'white but not quite' Eastern European woman feeds into a economy of sex and domestic labour which positions these individuals hierarchically. While the most oppressed ones are sexualized, racialized and commodified sex workers and domestic employees as 'the others'. In the case of Euro-Mediterranean relations, 'the others' are individuals and societies who disrupt the EU's spatial construction of Southern Mediterranean as a non-threatening space for EU security. In the case of irregular migration (including human trafficking), individuals are racialized as non-white sub-Saharan migrants, commodified as goods to be smuggled, and sexualized in the case of the white woman sex trade (Agathangelou, 2002 and 2004). Through externalization, hypermasculine practices of North African states are encouraged to stop these racialized, commodified and sexualized 'others' before they enter EU borders. Individuals and societies in Southern Mediterranean space, on the other hand, are hyperfeminized. This means that individuals and societies are rendered submissive to the state's policies with the purpose of constructing a society that is compatible with the interests of non-Western state (Ling, 2002). Before the Arab Spring, the hyperfeminization of certain individuals and societies was profoundly expressed by rendering them targets and/or tools of realizing EU's security objectives in cooperation with North African authoritarian regimes. These hyperfeminized groups disrupted the process in 2011.

To reiterate, the theoretical foundation of this analysis is mainly derived from a postcolonial feminist approach that focuses on global West/non-West relations. However, the Euro-Mediterranean relations reveal particular dynamics that have been neglected in this literature. First, the EU's hegemonic masculinity has a hybrid character, which also reproduces hybrid subordinated masculinity for Southern Mediterranean. Agathangelou (2004) strongly shows hypermasculinized political and economic processes in the Euro-Mediterranean area which result in racialization, commodification, and hyperfeminization of individuals in the specific case of sex trafficking. The current analysis brings the issue of counter-terrorism into the hypermasculinization of the Southern Mediterranean while highlighting the feminization of the same region in relation to democracy and human rights promotion. The focus on only one side of gendered spatial construction of the Southern Mediterranean is analytically incomplete. Secondly, in the case of Euro-Mediterranean relations, the EU's hybrid hegemonic masculinity not only involves hypermasculine characteristics but also reinforces hypermasculinity in order to promote the security interests of the EU. Therefore, 
hypermasculine ideologies and practices are not simply a strategy of the non-West against the West (for example, Bin Laden's hypermasculinity, Agathangelou and Ling, 2009: 16-17). They can also be assets that are reinforced by the West. Hypermasculine practices can be instrumentalized to keep the West secure as a result of processes such as externalization, which will be discussed below. Finally, a postcolonial feminist approach studies security mainly in relation to the self/other dichotomization. However, this dichotomy takes a different form when the West governs its security through subcontracting the non-West. Externalization is a novel process where 'seemingly subaltern actors can and do appropriate, and even 'refine', 'Western' security ideas, practices, institutions, and discourses for their own interest' (Hönke and Müller, 2012: 388). As a result, power relations are reproduced to prioritize the EU's and its collaborators' security interests: a construction of Southern Mediterranean as a non-threatening space for the EU while rendering hypermasculine North African states as the agents of European security.

(See Table 1, p. 23)

\section{Constructing Hybrid Euro-Mediterranean Space}

As part of the construction of a hybrid Euro-Mediterranean space, the Euro-Mediterranean Partnership was a milestone in 1995. The EMP's three-basket structure (political-security, economy, social and cultural) was formulated to promote the EU's security interests through facilitating political dialogue, democracy and human rights promotion, building a liberal economy that would contribute to the creation of political stability (Bilgin et.al., 2011: 12) and to the construction of a common identity in a Euro-Mediterranean space. With the EMP, the EU aimed to show Southern Mediterranean states and societies how to resolve conflicts (through CBMs and PBMs), how to prosper (through replicating a European model of free trade), and how to conduct domestic politics in the (neo)liberal world as a persuasive liberal 'father'. Having an enlightened self-interest, it also financed the partnership through instruments like MEDA. As a result, a hierarchical relationship between the EU and Southern Mediterranean emerged. This hierarchical relationship has been problematized within the literature as paternalistic, as Holm put it, 'like a asymmetry between the teacher and the pupil' (quoted in Bilgin, 2009: 14).

A gender reading of the Barcelona Process reveals that the EMP articulates EU's hegemonic masculine identity including, but also going beyond, paternalism. This hegemonic masculine identity has predominantly been framed based on the bourgeois-rational model of masculinity. In this political framework, the EU's masculine identity is constructed as a political actor who values dialogue over aggression and violence in conflict resolution, promotes capitalist development through free trade, and empowers civil society against the authoritarian practices of Southern regimes. Like a father, it is 
willing to show his son how things should be done in the neoliberal world order. As a result, a power hierarchy between the EU - whose identity is masculinized in accordance with the bourgeois-rational model (European, liberal, proactive, father) - and Southern Mediterranean - feminized vis-à-vis the former as being non-European, authoritarian, reactive, son - tailored. This gendered relationship was constructed to serve the 'father's security interests by creating a liberal-capitalist, and therefore stable, geographical space in which 'he' can ostensibly be secured.

The bourgeois-rational masculinity of the EU has been (re)constructed through the European Neighbourhood Policy (ENP) in 2004. Motivated by a goal to create a 'ring of friends' surrounding the EU (Solana, 2003), the ENP was formulated to answer the question: 'how best can we support our neighbours' political and economic transitions, and so tackle our citizens' concerns?' (quoted in Bilgin et.al., 2011: 14). Action Plans were formulated to pursue a more passionate democratization agenda while the EU Commission was given a mandate to monitor how Southern regimes implement the Action Plans. It can be argued that the EU's bourgeois-rational masculinity has found a new institutional manifestation with the ENP. However, in addition to this, another type of policy, which has constructed a hybrid Euro-Mediterranean space, was also adopted. Illiberal practices, as a result, were institutionalized in liberal Euro-Mediterranean space.

The ENP reflects the insecurity atmosphere in the EU, which 'acquired new urgency' after several terrorist attacks since 9/11 (EU Council, 2004: 3). As a response to this security concern, the EU has formulated a new security policy, identified in the literature as 'externalization' (Lavenex and Schimmelfennig, 2009; Lavenex and Wichmann, 2009). Externalization can be defined as the mode of governance through which the EU seeks to ensure the European Neighbourhood Policy's countries' participation in the realisation of its internal security project' (Lavenex and Wichmann, 2009). The EU's major internal security project is the construction of the Area of Freedom, Security and Justice for EU citizens. Externalization deals with security concerns of the West in the non-West with the cooperation of Southern neighbours, in order to prevent them from becoming internal security problems for the EU.

The process of externalization points to an alternative notion of security which underlines the citizenwarrior model of masculinity. According to this model, the citizen-warrior's main responsibility lies solely with his own community, and with protecting and promoting its interests even if this means inflicting harm on others. In this sense, instrumental rationality is powerfully in effect. It is possible to observe instrumental rationality underlying the ethnocentric security notion of the EU in irregular migration prevention policies. For example, it has been argued that the militarization of the Mediterranean actually contributed to directing migrants to more dangerous routes (Spijkerboer, 
2007; Lutterbeck, 2006). The EU has been criticized for violating the right to asylum both by scholars (Gammeltoft-Hansen, 2011) and international human rights organizations (Statewatch, 2012). In addition, the actor with the citizen-warrior model of masculinity does not hesitate to increase its control and domination of others (in this case, potential partners) by using a 'stick'. For example, in the Seville Presidency Conclusions (Council of the European Union, 2002), it was strongly emphasized that 'insufficient cooperation' of a neighbouring country with the EU in the area of irregular migration prevention would hinder 'closer relations' (para. 35). Other manifestations of such an approach include the increasing association of receiving developmental aid with capacity-building (Adapejo et.al., 2004) and rendering visa facilitation for citizens of North African states conditional upon signing readmission agreements with the EU. Although the literature has been critical to EU's policies in Southern Mediterranean (Boswell, 2011; Messari and Klaauw, 2011), what has been overlooked is that these security practices are constitutive to the EU's identity reflecting the citizen-warrior model.

In particular, patterns of cooperation in the areas of irregular migration prevention and counterterrorism come forward in the literature because of certain security practices of some European states, which appear to contradict the EU's vision to construct a democratic North Africa where human rights are promoted effectively. In relation to the former, the EU has aimed to construct North Africa as a buffer zone where asylum applications can be processed, irregular migrants can be contained, and irregular migrants in the EU can be repatriated (Bilgic, 2013: 113-124; Betts and Milner, 2006; De Haas, 2007). While some EU states funded the construction of migrant camps in North Africa (EU Commission 2004), the Mediterranean Sea has been militarized to detect smuggling boats (Lutterbeck, 2004) even through violating international law (Gammeltoft-Hansen, 2011). An implication of hypermasculine security practices to control migration is the otherization of subSaharan migrants in particular. Gendered representations of migrants as threats to national security and societal identities as hypermasculinized and feminized 'others' in the Mediterranean area have been documented (Kambouri and Zavos, 2011). In the Southern Mediterranean, sub-Saharan migrants are often represented at state and societal level as source of crime and violence (hypermasculinization) and of prostitution, sickness, and immorality (feminization) (Bensaad, 2007). As a result, the hypermasculine security practices that the EU has reinforced, such as migration camps, are justified. The use of migrant camps in North Africa, despite reports about severe human rights violations (Amnesty International 2004, Fortress Europe 2007, Human Rights Watch 2006 and 2011) and attempts to convert North African countries into a buffer zone despite of the welldocumented insecurities of migrants in these countries (see, Bensaad, 2007; FIDH, 2011) point to how hypermasculinized Southern Mediterranean is used by the EU. 
In addition, counterterrorism cooperation has been perceived in Southern Mediterranean societies as the most advanced between the EU and Southern regimes (Wolff, 2009), although the practice suggests otherwise. As Kaunert and Leonard (2011: 302) show, the rhetoric of cooperation in this area is more powerful than in operational cooperation. However, through this rhetoric precisely, Southern Mediterranean states are hypermasculinized and societies hyperfeminized. The EU's rhetoric on counterterrorism cooperation with Southern Mediterranean holding questionable democratic credentials has repeatedly appeared in Euro-Mediterranean documents. This rhetoric on the EU's willingness to cooperation has provided, as Nicolaidis and Nicolaidis (2004) highlight, 'a new lease of life' to the pre-Arab Spring authoritarian regimes (quoted in Bilgin et. al., 2011: 30). Throughout the 2000s, problematic counter-terrorism policies (such as illegalization of creating a crowd in Algeria, searching domiciles without a warrant in Morocco) were introduced (Bilgin et. al. 2011: 18-19). For this reason, Kausch and Young (2009) strongly criticize the ENP for pacing away from a security vision based on democratization and human rights to a vision about control and surveillance, due to EU members states' reservations towards Islamist civil society. Hence, in some sectors of the Southern Mediterranean, the idea has emerged that North Africa is doing the 'dirty work' of the EU (Bilgin and Bilgic, 2011: 7). With these policies, hypermasculinized Southern Mediterranean states obtained a stronger grip on hyperfeminized societies. As a result, 'the individual [wa]s manifestly less protected on both sides of the Mediterranean' (Galli, 2008).

These dualities have served to continue the gendered power hierarchy since 1995 in an institutionalized way. The illiberal security practices are constitutive to hypermasculinized Southern Mediterranean states within the liberal feminized Southern Mediterranean space. The Arab Spring, however, has created a disruption of these hybrid gendered identities as some partners of the EU were toppled. The last section of the article will examine the EU's reaction to the transformations in some Southern Mediterranean countries, and its consequences for EU's hybrid hegemonic masculinities.

\section{Post-Arab Spring Euro-Mediterranean Security Relations}

What happened following the self-immolation of Muhammed Bouazizi in Tunisia and the brutal murder of Khalid Said, blogger and activist, in Egypt can be considered, in Arendt's words (1978: 7), as an 'event' that interrupted 'routine processes and routine procedures' in many North Africa countries. The event, in its most well-known Euro-centric name, was the Arab Spring, which was the uprising of individuals who coped with their powerlessness (ajz) in order to obtain dignity (al-karama) (Hassan, 2012: 234). Given the current situation, it is early to pass judgements about the consequences of the uprisings for the region. Yet, it is possible to argue that 'life shattering experiences' such as 
oppression and poverty led people, who were previously considered as 'traditional' in Western imagination, 'to organize, against and also intervene in the repressive mechanisms that limit their lives' (Agathangelou and Soguk, 2013: 2-3). The Euro-Mediterranean space has been constructed at the expense of individuals' and social groups' security which concerns the removal of repressive mechanisms that limit human freedoms. In other words, this hybrid space has been one of those repressive mechanisms within the global West/non-West relations.

It has so far been argued that the EU has constructed a hybrid gendered identity regarding its Southern neighbourhood. This hybrid identity has reverberated onto the Southern neighbourhood by constructing a Euro-Mediterranean space where both liberal and illiberal practices can be performed in order to promote the EU security interests. Feminization and hypermasculinization of Southern Mediterranean in relation to different security issues are instrumental to constructing this space. However, the EU's Southern partners were generally unpopular regimes some of which were eventually toppled during the Arab Spring. Given the criticisms that the EU previously received in relation to cooperation with the former unpopular regimes (see above), the EU seems to realize the novelties in the region and tries to reformulate its policies (EU Commission, 2011a and 2011b, 2013). However, the question appears: to what extent can the new policies of the EU and the new perspective underlining them create a difference in the gendered power hierarchy in EuroMediterranean security relations? The difference can be traced in two areas. First, will feminization of Southern Mediterranean states and societies in relation to democracy and human rights promotion continue? Or will the EU, abandoning its liberal 'father' who teaches his son how to do things in neoliberal world, accepts the agency of Southern Mediterranean societies not as 'a footnote to the West's history nor [as] an appendix to neoliberal capitalist projects' but as direct contributors to 'global just politics' (Agathangelou and Soguk, 2013: 2)? Second, will hypermasculinization of Southern neighbourhood continue through the policies of externalization, which hyperfeminize certain individuals, particularly irregular migrants? In other words, the question asks whether the security of individuals and societies in the Euro-Mediterranean space will be taken into consideration in the post-Arab Spring era or whether the Euro-Mediterranean space will again be constructed to justify Western intervention for the promotion of EU security interests.

In spite of the new rhetoric adopted in the EU documents about democracy promotion, more substantial civil society participation along with new financial documents with increased budgets for capacity-building for democratization (for example, SPRING (Support for Partnership, Reform and Inclusive Growth) with EUR 540 in Southern Mediterranean, see EU Commission, 2013: 10), the new perspective seems to re-bottle the old wine. As such it aims to maintain the hybrid gendered power hierarchy in Euro-Mediterranean security relations. Among the wide range of policies, two are 
selected for discussion due to the bourgeois-rational and citizen-warrior models of masculinity crystallized in them: the Partnership for Democracy and Shared Prosperity with the Southern Mediterranean (PDSP) and migration control.

One of the most important policy practices, which can potentially challenge the gendered power hierarchy in Euro-Mediterranean security relations, is promotion of individual and societal securities through empowerment. In this way, local security concerns such as lack of political rights and freedoms, poverty, unemployment, and domestic violence are prioritized. PDSP was launched by the EU Commission in 2011 in order to support democratic transitions in the Southern neighbourhood. In fact, PDSP involves a potential for constructing a different Euro-Mediterranean space. For example, the document explicitly shows that the political transformation of North Africa 'will be developed by listening not only to requests for support from partner governments, but also to demands expressed by civil society' (EU Commission, 2011a: 3). While Southern Mediterranean states are encouraged for reform to achive 'advanced status' in their relations with the EU, civil society actors are considered as the source of 'much-needed support for the reforms and involvement in areas close to citizens' concerns such as human rights, the environment, social and economic development' (6).

However, a detailed analysis of the program reveals that the EU has maintained (and re-constructed) the bourgeois-rational hegemonic masculinity towards Southern Mediterranean. First, the Partnership, similarly to previous attempts, prioritizes the bourgeois-rational approach of having a free-market for democratization while merely acknowledging the importance of social justice; second, the Program is black-boxing civil society without touching the important well-known problems such as quasi-governmental NGOs or governmental control over financial aid from the EU to civil society in Southern Mediterranean; third, very crucial civil society actors during the Arab Spring, trade unions and other labour organizations, are not given the necessary importance in the Program (Teti, 2012: 273-275). Hence, the 'new' partnership maintains 'the distinction between political and socio-economic rights characteristic of 'minimalist' (neo)liberal definitions of democracy' (276). It is indeed the fact that the EU has not paid attention to, for example, Islamist civil society organizations which resisted along with the secular movements during the Arab Spring (Mamdani, 2013: 13). Real individual security issues such as domestic violence were also overlooked, while gender equality is only limited to lip-service regarding equal participation of women to 'political and economic life' (EU Commission, 2011b). Civil Society Neighbourhood Facility is already a questionable formation while its predecessor Euro-Mediterranean Civil Society Forum (founded in 1995) was eventually disempowered and the Commission itself stopped sending a representative. In other words, the EU seems to continue to feminize Southern Mediterranean state and civil society by 
expecting them to follow the EU's democratization agenda without giving due attention to realities of Southern Mediterranean countries.

The second dimension of the EU's 'new' approach in the post-Arab Spring era towards the Southern Mediterranean is the issue of migration control. It must be noted that the EU has adopted a more comprehensive and practical mobility scheme between EU and Southern Mediterranean states. However, as in the previous attempts, this mobility scheme is made conditional upon partner states' willingness to cooperate with the EU in the area of irregular migration prevention (EU Commission, 2011b: 11). In other words, the mobility partnerships seem to be 're-branding of existing visa facilitation policies' (Echagüe et. al., 2011: 331). In terms of capacity-building in the fight against 'illegal' migration following the fall of authoritarian regimes, EU member states have been quick to sign new bilateral agreements (for example the Italy-Tunisia agreement of 2011 promising aid for Tunisia's cooperation to stop further departures), while the EU has also followed member states' practices. 'In a visit to Tunis by Commission President Barroso in April 2011, it was made clear that the EU's offer of around $€ 400$ million of aid to support Tunisia's democratic transition would necessitate reciprocal actions to counter irregular migration' (Carrera et. al., 2012: 5-6, for member state 'fears' of migrant influx from Southern Mediterranean, see Dennison, 2013: 125). In addition, the EU has so far shown no inclination to revise the much-disputed FRONTEX operations in the Mediterranean (for criticisms of FRONTEX operations between 2011 and 2013, see Human Rights Watch, 2011; Statewatch, 2012 and Sunderland, 2013). None of the documents the EU produced after 2011 on Southern Mediterranean relations offered a specific policy to address the security problems that irregular migrants face in North Africa (FIDH, 2011). Irregular migration only appears as a problem to be tackled through control and domination. Hypermasculinized externalization is likely to continue.

Given the aforementioned continuities in the EU's approach to the Southern Mediterranean in the post-Arab Spring era, it can be argued that the EU aims to reconstruct the hybrid Euro-Mediterranean space by subordinating the Southern Mediterranean through feminizing and hypermasculinizing it. In the area of democracy promotion, the EU adopts the bourgeois-rational masculine identity by acting like a capitalist, developed, paternal figure towards 'infant' Southern Mediterranean countries, especially towards Southern Mediterranean civil society. EU's security is still regarded as conditional upon a democratic Southern Mediterranean, which can be built on the EU's terms. On the other hand, when it comes to the issue of migration control, the EU's citizen-warrior masculine identity dominates, and the EU continues its externalization practices, which result in a hypermasculinized subordinated Southern Mediterranean. 


\section{Conclusion}

In this article, I argued that the Euro-Mediterranean security relations embody a gendered power hierarchy between the hybrid hegemonic masculinity of the (bourgeois-rational and citizen-warrior) EU and the subordinate (both feminized and hypermasculinized) Southern neighbourhood. In addition, after the Arab Spring, the EU has been determined to maintain the status quo by preserving these gendered power relations. This is because feminizing and hypermasculinizing the Southern neighbourhood is instrumental to construct a secure geographical space for the EU. This gender analysis differs from the literature on Euro-Mediterranean relations because of its specific focus on the (re)construction processes of gendered identities in tandem with the EU's competing notions of security. Therefore, it can be called a feminist intervention on the issue. Departing from the idea that the notions of security and political identity construction processes are inseparable, it was highlighted that the examination of the gendered dimension of identity construction processes can provide a more insightful perspective to reveal how power operates in the Euro-Mediterranean securityidentity nexus. In addition, this gendered perspective can enable an analysis of feminist ideas and practices challenging the hierarchical identities in Euro-Mediterranean security relations.

The EU's hegemonic masculinity is a fluid and dynamic identity, which can be transformed in accordance with changing political and social conditions. The increasing inclusion of the characteristics of the citizen-warrior model to the hegemonic masculine identity of the EU in the post-9/11 era points to this adaptability and dynamism of masculinities. Second, masculinities (hegemonic or not) are not monolithic, but inclusive to different, even clashing, elements. The most explicit expression of this argument is the duality of the EU's hegemonic masculinity. On the one hand, reflecting the bourgeois-rational model, it acts like an enlightened father who is willing to teach his son the conditions of peaceful co-existence in the liberal world by upholding democracy, human rights and freedoms, and values of free market economy. On the other hand, the citizen-warrior EU prioritizes its own domestic security and takes 'necessary' measures even if these measures have the potential to harm others. An important contribution of gendered analysis is to show that these two competing masculinities generating the EU's hegemonic masculinity co-exist because they jointly serve the EU's competing security notions. The hegemonic masculinity of the EU dominating the EMP period was effeminizing Southern Mediterranean masculinities as politically, economically and socially underdeveloped, and therefore, needing of guidance and support of a superior authority. In this way, the EU has been able to reconfigure relations where power lies with itself as opposed to non-European, authoritarian, economically and socially weak Southern Mediterranean. However, with the ENP and especially with the policy of externalization, conflicting with its earlier position, the EU has reinforced the hypermasculinization of Southern Mediterranean. 


\section{Acknowledgements}

Parts of this article were presented at the 7th Pan-European Conference on the European Union, ECPR, June 5-7, 2014, The Hague. I would like to thank anonymous referees and the editor for the comments. My special thanks go to Athina Gkouti.

\section{References}

Adepoju, A., F. Van Noorloos, and A. Zoomers (2010) Europe's Migration Agreements with Migrant-Sending Countries in the Global South: A Critical Review, International Migration, 48(3), pp. $42-75$.

Agathangelou, A.M. (2004) The Global Political Economy of Sex: Desire, Violence, and Insecurity in Mediterranean Nation States. (Hampshire: Palgrave Macmillan).

Agathangelou, A.M. (2013) Making Anew an Arab Regional Order? On Poetry, Sex and Revolution, in: A.M. Agathangelou and N. Soguk (Eds) Arab Revolutions and World Transformations (London: Routledge).

Agathangelou, A.M. and L.H.M. Ling (2009) Transforming World Politics: From Empire to Multiple Worlds (London: Routledge).

Agathangelou, A.M. and L.H.M. Ling (2004) Power, Borders, Security, Wealth: Lessons of Violence and Desire from September 11, International Studies Quarterly, 48, pp. 517-538.

Agathangelou A.M. and N. Soguk (2013) Rocking the Kasbah: Insurrectional Politics, the "Arab Streets", and Global Revolution in the 21st Century, in: A.M. Agathangelou and N. Soguk (Eds) Arab Revolutions and World Transformations (London: Routledge).

Amnesty International (2004) Libya: Time to Make Human Rights a Reality.

Arendt, H. (1978) The Human Condition. Chicago: University of Chicago Press.

Beasley, C. (2008) Rethinking hegemonic masculinity in a globalizing world, Men and Masculinities, 11(1), pp. 86-103.

Bensaad, A. (2007) The Mediterranean Divide and its Echo in the Sahara: New Migratory Routes and New Barriers on the Path to the Mediterranean, in: T. Fabre and P. Sant Cassia (Eds) Between Europe and the Mediterranean: The Challenge and the Fears (Hampshire: Palgrave Macmillan).

Betts, A. and J. Milner (2006) The Externalization of EU Asylum Policy: the Position of African States, University of Oxford Centre on Migration, Policy, and Society Working Paper No: 36.

Bilgic, A. (2011) Rethinking Security in the Age of Migration: Trust and Emancipation in Europe (London: Routledge).

Bilgic, A. (2012) The Qualitative Analysis of the Results of the IEMed Survey 2011 Regarding the EuroMediterranean Political and Security Cooperation in the Wake of the Arab Spring, Euromed Survey of Experts and Actors, European Institute of the Mediterranean, Barcelona. 
Bilgin, P. (2009) An analysis of the state of the art in the European Union's security policies towards the Mediterranean with special focus on the value premises embedded, IN:EX Deliverable, Available at

http://www.inexproject.eu/index.php?option=com_docman\&task=doc_view\&gid=40\&tmpl=compon ent\&format=raw\&Itemid=72 (accessed 29.11.12)

Bilgin, P. and A. Bilgic (2011) Consequences of European Security Practices in the Southern Mediterranean and Policy Implications for the EU. IN: EX Policy Brief No. 12.

Bilgin, P., E. S. i Lecha, A. Bilgic (2011) European Security Practices vis-à-vis the Mediterranean Implications in Value Terms, DIIS Working Paper No: 14.

Biswas, S. (2002) The "New Cold War": Secularism, Orientalism and Postcoloniality, in G. Chowdhry and S. Nair (Eds) Power, Postcolonialism and International Relations: Reading Race, Gender and Class (London: Routledge).

Boswell, C. (2011) Migration Control and Narratives of Steering, The British Journal of Politics and International Relations, 13(2), pp. 12-25.

Caprioli, M. (2004) Democracy and Human Rights Versus Women's Security: A Contradiction?, Security Dialogue, 35(4), pp. 411-428.

Carrera, S., L. den Hertog and J. Parkin (2012) EU Migration Policy in the wake of the Arab Spring: What prospects for EU-Southern Mediterranean Relations?, MEDPRO Technical Report No. 15.

Connell, R. W. (2005) Masculinities (California: University of California Press, $2^{\text {nd }}$ edition).

Council of the European Union (2004) The Hague Programme: Strengthening Freedom, Security and Justice in the European Union.

Das, R. (2003) Postcolonial (in)securities, the BJP and the politics of Hindutva: Broadening the security paradigm between the realist and anti-nuclear/peace groups in India, Third World Quarterly, 24(1), pp. 77-96.

De Haas, H. (2007) The myth of invasion: Irregular migration from West Africa to the Maghreb and the European Union. University of Oxford. James Martin 21st century school. International migration institute.

Debusscher, P. (2012) Mainstreaming Gender in European Union Development Policy in the European Neighborhood, Journal of Women, Politics \& Policy, 33(4), pp. 322-344.

Dennison, S. (2013) The EU and North Africa after the Revolutions: A New Start of 'plus ça change'?, Mediterranean Politics, 18(1), pp. 119-124.

Doty, R. (1996) Imperial Encounters (Minneapolis: University of Minnesota Press).

Echagüe, A., H. Michou and B. Mikail (2011) Europe and the Arab Uprisings: EU Vision versus Member State Action, Mediterranean Politics, 16(2), pp. 329-335. 
Eichler, M. (2011) Russian Veterans of the Chechen Wars: A Feminist Analysis of Militarized Masculinities, in: J.A. Tickner and L. Sjoberg (Eds) Feminism and International Relations: Conversations about the Past, Present and Future (London: Routledge).

Elder, G. (2005) Somewhere, Over the Rainbow: Cape Town, South Africa, as a "Gay Destination", in: L. Ouzgane amd R. Morrell (Eds) African Masculinities: Men in Africa from the Late Nineteenth Century to the Present (Hampshire: Palgrave).

EU Commission (2000) From the Single Act to Maastricht: The Means to Match Our Ambitions, $\operatorname{COM}(92) 2000$ Final.

EU Commission (2004), Technical Mission to Libya on Illegal Immigration.

EU Commission (2011a) A Partnership for Democracy and Shared Prosperity, COM(2011) 200 final.

EU Commission (2011b) Joint Communication by the High Representative of The Union For Foreign Affairs And Security Policy and the European Commission, Brussels.

EU Commission (2013) European Neighbourhood Policy: Working towards a Stronger Partnership, JOIN(2013) 4 final.

FIDH (2011) Exiles From Libya Flee to Egypt: Double Tragedy for Sub-Saharan Migrants.

Fortress Europe (2007) Escape from Tripoli: Reports on the Conditions of Migrants in Transit in Libya.

Galli, F. (2008) The Legal and Political Implications of the Securitization of Counter-Terrorism Measures across the Mediterranean, EuroMesCo Paper No: 71.

Gammeltoft-Hansen, T. (2011) Access to Asylum: International refugee law and the globalisation of migration control, (Cambridge: Cambridge University Press).

Han, J. and L. H. M. Ling (2002) Authoritarianism in the hypermasculinized state: Hybridity, patriarchy, and capitalism in Korea, International Studies Quarterly, 42(1), pp. 53-78.

Harders, C. (2003) Gender and Security in the Mediterranean, Mediterranean Politics, 8(2-3), pp. 5472.

Hassan K. (2012) Making Sense of the Arab Spring: Listening to the Voices of Middle Eastern Activists. Development, 55(2): 232-238.

Hooper, C. (1998) Masculinist Practices and Gender Politics: The Operation of Multiple Masculinities in International Relations, in: M. Zalewski, and J. Parpart (Eds) The "Man" Question in International Relations (Boulder:Westview).

Hooper, C. (2001) Manly States: Masculinities, international relations, and gender politics (New York: Columbia University Press).

Hönke, J. and M.M. Müller (2012) Governing (in) security in a postcolonial world: Transnational entanglements and the worldliness of 'local'practice, Security Dialogue, 43(5), pp. 383-401. 
Human Rights Watch (2006) Stemming the Flow: Abuses Against Migrants, Asylum-Seekers and Refugees, (September, 2006).

Human Rights Watch (2011) The EU's Dirty Hands: Frontex Involvement in III-Treatment of Migrant Detainees in Greece, Available at http://www.hrw.org/sites/default/files/reports/greece0911webwcover_0.pdf (accessed 28.08.2013)

Human Rights Watch (2011b) 'Tunisia: Protect Migrant Camp Residents', 23 June 2011, Available at http://www.hrw.org/news/2011/06/23/tunisia-protect-migrant-camp-residents (accessed 28.08.2013)

Jünemann, A. (2002) From the bottom to the top: civil society and transnational non-governmental organizations in the Euro-Mediterranean Partnership, Democratization, 9(1), pp. 87-105.

Jünemann, A. (2003) Security-building in the Mediterranean after September 11, Mediterranean Politics 8(2-3), pp. 1-20

Kambouri, N. and A. Zavos (2011) Gender, Migration and Intercultural Interactions in the Mediterranean and South East Europe. Final Synthesis Report. Ge. M. IC. Panteion University (UPSPS), Greece.

Kaunert, C. and S. Leonard (2011) EU counterterrorism and the European neighbourhood policy: an appraisal of the southern dimension, Terrorism and political violence, 23(2), pp. 286-309.

Kausch, K., and R. Youngs (2009) The End of the Euro-Mediterranean Vision, International Affairs, 85(5), pp. 963-975.

Kronsell, A. (2005) Gendered practices in institutions of hegemonic masculinity, International Feminist Journal of Politics, 7(2), pp. 280-298.

Laffey, M. and S. Nadarajah (2012) "The hybridity of liberal peace: States, diasporas and insecurity", Security Dialogue, 43(5), pp. 403-420.

Lavenex, S. and F. Schimmelfennig (2009) EU rules beyond EU borders: theorizing external governance in European politics, Journal of European Public Policy 16(6), pp. 791-812.

Lavenex, S. and N. Wichmann (2009) The external governance of EU internal security, European Integration, 31(1), pp. 83-102.

Ling, L. H. M. (2000) Hypermasculinity on the Rise, Again: A Response to Fukuyama on Women and World Politics, International Feminist Journal of Politics, 2(2), pp. 277-286.

Ling, L.H.M. (2002) Cultural Chauvinism and the Liberal International Order: "West versus Rest" in Asia's Financial Crisis, in: G. Chowdhry and S. Nair (Eds) Power, Postcolonialism and International Relations: Reading Race, Gender and Class (London: Routledge).

Lister, M., and M. Carbone (eds.) (2006) New Pathways in International development: Gender and Civil Society in EU Policy (Aldershot: Ashgate).

Lutterbeck, D. (2004) Between Police and Military: The New Security Agenda and the Rise of Gendarmeries, Cooperation and Conflict, 39(1), pp. 45-68. 
Lutterbeck, D. (2006) "Policing migration in the Mediterranean." Mediterranean Politics, 11(1), pp. 5982.

Mamdani, M. (2013) An African Reflection on Tahrir Square, in: A.M. Agathangelou and N. Soguk (Eds) Arab Revolutions and World Transformations (London: Routledge).

Messari, N. and J. Van Der Klaauw (2011) Counter-terrorism Measures and Refugee Protection in North Africa, Refugee Survey Quarterly, 29, pp. 83-103.

Mohanty, C.T. (2006) Feminism without Borders: Decolonizing Theory, Practicing Solidarity (London: Duke University Press).

Munn J. (2008) National Myths and the Creation of Heroes, in: J.L. Parpart and M. Zalewski (Eds) Rethinking the Man Question: Sex, Gender and Violence in International Relations (London: Zed Books).

Muppidi, H. (1999) Postcoloniality and the Production of International Insecurity: The Persistent Puzzle of U.S.-Indian Security Relations, in: J. Weldes (Ed) Cultures of Insecurity (Cambridge: Cambridge University Press).

Nandy, A. (1983) The Intimate Enemy: Loss and Recovery of Self Under Colonialism (New Delhi: Oxford University Press).

Nicolaidis, K. A. and D. Nicolaidis (2007) The EuroMed Beyond Civilizational Paradigms, Institute of European Studies, University of California.

Niva, S. (1999) Contested Sovereignties and Postcolonial Insecurities in the Middle East, in: J. Weldes (Ed) Cultures of Insecurity (Cambridge: Cambridge University Press).

Ouzgane, L. and D. Coleman (1998) Postcolonial masculinities: introduction, Jouvert: A Journal of Postcolonial Studies, 2(1), pp. 1-10.

Schmid, D. (2004) The Use of Conditionality in Support of Political, Economic and Social Rights: Unveiling the Euro-Mediterranean Partnership's True Hierarchy of Objectives?, Mediterranean Politics, 9(3), pp. 396-421.

Slater, D. (2004) Geopolitics and the post-colonial: Rethinking the North-South Relations (Oxford: Blackwell).

Solana, J. (2003) A secure Europe in a better world: European security strategy.

Spijkerboer, T. (2007) The Human Costs of Border Control, European Journal of Migration and Law, 9, pp 127-139.

Spurr, D. (1993) The Rhetoric of Empire (Durham: Duke University Press).

Statewatch (2012) Criticism of Frontex's operations at sea mounts. Available at http://www.statewatch.org/analyses/200-frontex-search-rescue.pdf (accessed 28.08.2013) 
Sunderland, J. (2013) Frontex Should Respect Rights, Even on the High Seas, European Voice, 06.06.2013. Available at http://www.hrw.org/news/2013/06/06/frontex-should-respect-rights-evenhigh-seas (accessed 28.08.2013)

Teti, A. (2012) The EU's First Response to the 'Arab Spring': A Critical Discourse Analysis of the Partnership for Democracy and Shared Prosperity, Mediterranean Politics, 17(3), pp. 266-284.

The European Council (2002) Presidency Conclusions, Seville.

Tickner, J.A. (1992) Gender in international relations: Feminist perspectives on achieving global security (New York: Columbia University Press).

Tickner, J.A. and L. Sjoberg (2011) Conclusion: Looking forward for feminist International Relations, in: J.A. Tickner and L. Sjoberg (Eds) Feminism and International Relations: Conversations about the Past, Present and Future (London: Routledge).

Wolff, S. (2009) The Mediterranean Dimension of EU Counter-terrorism, European Integration, 31(1), pp. 137-156.

Youngs, G. (2004) Feminist International Relations: a contradiction in terms? Or: why women and gender are essential to understanding the world 'we'live in, International Affairs, 80(1), pp. 75-87.

Zalewski, M. (1998) From the Women Question to the Man Question in International Relations, in: M. Zalewski and J. Parpart (Eds) The "Man" Question in International Relations (Boulder:Westview).

Zalewski, M. (2010) Feminist International Relations: Making Sense..., in: L. Sjoberg (Ed) Gender Matters in Global Politics: A Feminist Introduction to International Relations (London: Routledge). 


\begin{tabular}{|l|l|l|l|l|}
\hline & $\begin{array}{l}\text { Masculinity of the } \\
\text { EU }\end{array}$ & Issues & Notion of Security & $\begin{array}{l}\text { Subordinated } \\
\text { Masculinity of }\end{array}$ \\
\hline & $\begin{array}{l}\text { Sourgeois-rational } \\
\text { (Rational, } \\
\text { democratic, } \\
\text { capitalist, } \\
\text { developed, guiding } \\
\text { father) }\end{array}$ & $\begin{array}{l}\text { Democracy and } \\
\text { Human Rights } \\
\text { Protection and } \\
\text { Promotion }\end{array}$ & $\begin{array}{l}\text { Lemocran } \\
\text { market economy } \\
\text { and a balance } \\
\text { between state and } \\
\text { security is a way }\end{array}$ & Feminized \\
\hline
\end{tabular}




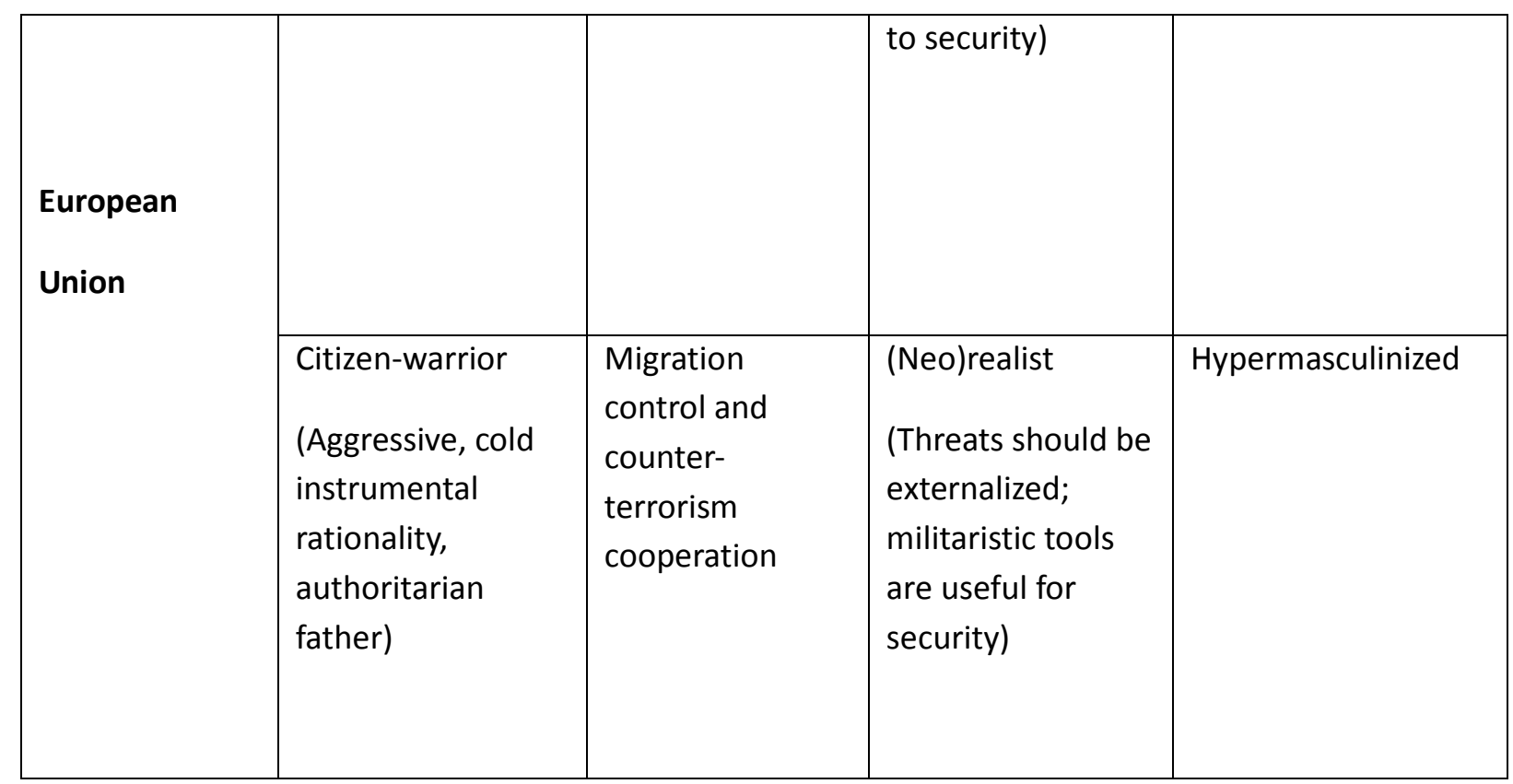

Table 1: Hybrid Euro-Mediterranean Space 